\title{
Experiential Learning Theory: From Theory To Practice
}

Mary McCarthy, Nova Southeastern University, USA

\begin{abstract}
This paper examines Kolb's (1984) Experiential Learning Theory and Learning Style Inventory, presents a summary of some research examining accounting students' learning style preferences, and provides examples of activities to incorporate into the instructional environment that encourages learning through experience.
\end{abstract}

"I hear and I forget. I see and I remember. I do and I understand" Confucius (551 BC-479 BC).

Keywords: Experiential learning theory; Kolb's learning styles inventory; active learning

\section{INTRODUCTION}

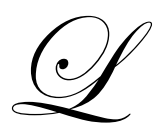

earning styles have been the focus of many studies over the past thirty years in an effort to improve the instructional design of courses and understand how students learn. Four approaches to learning have been examined: (1) personality (2) information processing, (3) social interaction, and (4) instructional preferences.

The first approach, personality, contains research that describes personality types or character traits. Based on Jungian psychology, Myers-Briggs Type Indicator (MBTI) is one of the most widely known and used analysis of personality. MBTI examines how the individual perceives the world and makes decisions. The second approach, information processing, examines how students absorb and use new information. David Kolb's experiential learning model and learning styles inventory (LSI) is the most prominent theory and instrument used. The experiential learning model is a four stage circular process where for effective learning to occur, the learner must experience the entire cycle. Most students favor one part of the cycle over other parts hence their learning style preference. However, learning styles are not fixed and can change. The third approach, social interaction, focuses on how students behave in the classroom. A popular model, the Fuhrmann and Jacobs model classifies learners as dependent, collaborative, and independent. The fourth approach, instructional preferences, focuses on teaching methods and the learning environment. The Canfield Learning Style Inventory is a well known instrument for evaluating student instructional preference (Francis, Mulder, \& Stark, 1995).

This paper examines the second approach, information processing. Kolb's experiential learning theory, the Learning Style Instrument for determining learning style preference, and how to effectively incorporate experiential learning theory into practice is reviewed. Integrating experiential learning theory into practice can be a daunting challenge for accounting faculty as we attempt to oblige different learning styles as well as our own learning style. However it is possible to develop instructional design to accommodate all learning styles through active learning.

Experiential learning, or active learning, interactive learning, or "learning by doing" has resulted in positive outcomes. Most experts agree that when students take an active role in the learning process the student's learning is optimized (Smart \& Csapo, 2007).

This paper has important implications for accounting education. First, by understanding experiential learning theory and linking to practice in the classroom, educators are better equipped to promote learning. Second, the paper highlights areas for future research to further our knowledge and understanding of accounting student's learning styles. 
The remainder of the paper is organized as follows: First, a discussion on Kolb's Experiential Learning Theory and Learning Styles is discussed followed by some of the more important prior accounting research using Kolb's Learning Style Inventory instrument. Then, a discussion on using experiential techniques in the classroom and recommendations for future research is provided. Lastly, a summary of the paper is given.

\section{RELEVANT LITERATURE}

\section{Kolb Experiential Learning Theory and Learning Styles}

Experiential Learning Theory (ELT) has its roots in the experiential works of Dewey, Lewin, and Piaget. Unlike cognitive learning theories, which tend to emphasize cognition over affect, and behavioral learning theories, which do not allow any role for consciousness and subjective experience in the learning process, experience plays a central role in ELT's process. ELT is intended to be a holistic adaptive process on learning that merges experience, perception, cognition, and behavior. Previous research has shown that learning styles are influenced by personality type, educational specialization, career choice, current job role and tasks, and cultural influences (Kolb, 1984, Kolb \& Kolb, 2005).

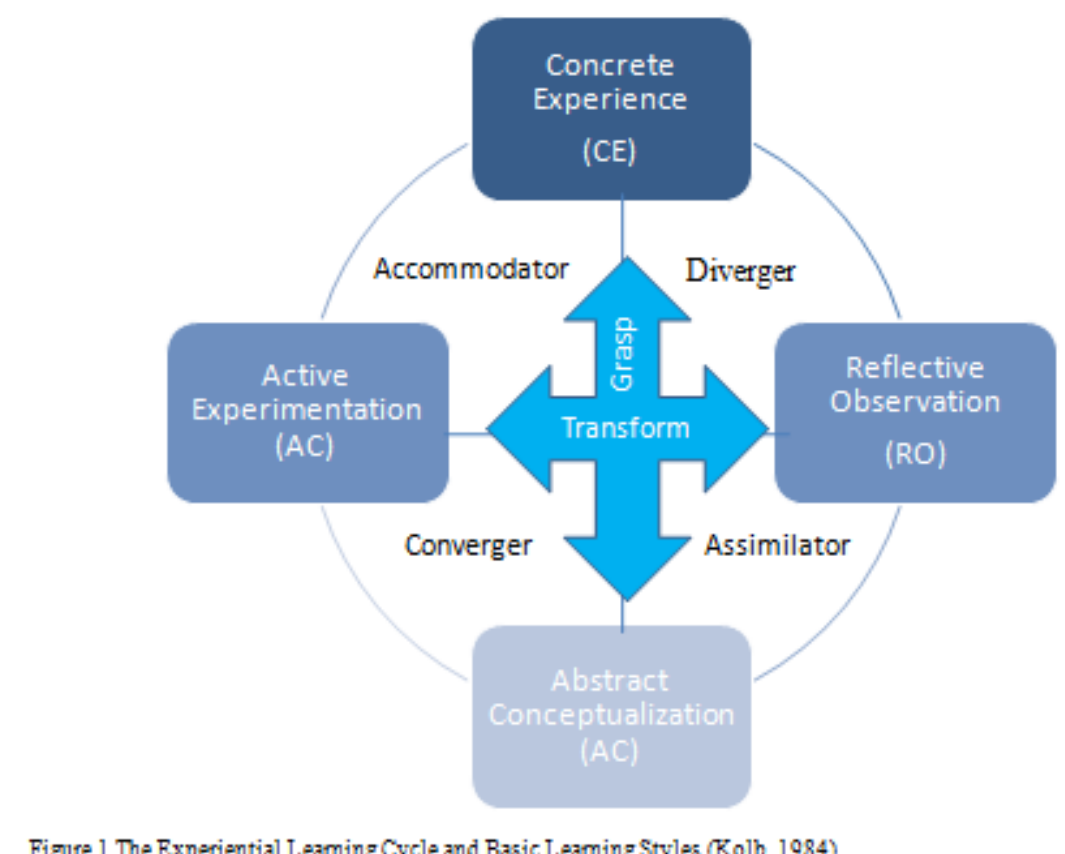

Figure 1 The Experiential Leaming Cycle and Basic Leaming Styles (Kolb, 1984).

ELT defines learning as "the process whereby knowledge is created through the transformation of experience. Knowledge results from the combination of grasping and transforming experience" (Kolb, 1984, p.41). The experiential learning model is a cyclical process of learning experiences. For effective learning to transpire, the learner must go through the entire cycle. The four stage learning model depicts two polar opposite dimensions of grasping experience - concrete experience (CE) and abstract conceptualization (AC), and two polar opposite dimensions of transforming experience - reflective observation (RO) and active experimentation (AE). Experiential learning is a process of constructing knowledge that involves a creative tension among the four learning abilities. The learner must continually choose which set of learning abilities to use in a specific learning situation. As mentioned, learning is conceived as a four stage cycle (see Figure 1) where the learner must go through each stage experiencing, reflecting, thinking, and acting. In the grasping experience the learner can perceive new information through experiencing the concrete, tangible, felt qualities of the world, relying on their senses and immersing themselves in concrete reality. Or the learner can experience the opposite, abstract conceptualization. This learning 
style preference would tend to perceive, grasp, or take hold of new information through symbolic representation thinking about, analyzing, or systematically planning. In the transforming experience the reflective observation ability tends to observe others who are involved in the experience and reflect on what happens while the active experimentation stage favors jumping in and starting doing things. It is important to note that the learner can enter the model at any stage (Kolb, 1984).

The Learning Style Inventory (LSI), the instrument used to assess the individual learning styles, identifies four types of learners based on their approach to obtain knowledge- Diverger, Assimilator, Converger, and Accommodator (see Figure 1).

Divergers prefer to approach learning through Concrete Experience (CE) and to process it through Reflective Observation (RO). Divergers are best at viewing existing situations from many different points of view. Individuals perform better in situations requiring generating new ideas and brainstorming. Their strength lies in imaginative ability and awareness of meaning and values. They tend to have broad cultural interests, are interested in people, and are feeling oriented. Accommodators also prefer to take in knowledge through concrete experience, however they favor processing it through active experimentation ideas (Kolb, 1984, Kolb, Boyatzis, and Mainemelis, 1999, Geiger, 1992).

Accommodators have the ability to learn from primarily "hands-on" experience. They enjoy carrying out plans and involving themselves in new and challenging experiences. They may tend to act on their "gut" feeling rather than on logical analysis. In solving problems, accommodators rely more heavily on people for information than on their own technical analysis. They tend to be adaptive and risk-taking and perform well in situations where they must change to meet immediate circumstances. They are at ease with people but sometimes can come across as impatient (Kolb, 1984, Kolb, Boyatzis, \& Mainemelis, 1999, Geiger, 1992).

The assimilator prefers to approach knowledge through abstract conceptualization and to process it through reflective observation. Assimilators are best at understanding a wide range of information and putting the information into a concise, logical form. Their strength lies in inductive reasoning and the ability to create theoretical models. Assimilators are less focused on people and more interested in ideas and abstract concepts. Generally, assimilators find it more important that a theory have logical soundness than practical value ideas (Kolb, 1984, Kolb, Boyatzis, \& Mainemelis, 1999, Geiger, 1992).

The converger also approaches knowledge through abstract conceptualization however the converger favors processing it through active experimentation. Convergers prefer to deal with technical tasks and problems rather than with social and interpersonal issues. Their strength lies in problem solving, decision making, and the practical application of ideas (Kolb, 1984, Kolb, Boyatzis, \& Mainemelis, 1999, Geiger, 1992).

\section{Learning Style Inventory - The Instrument}

In 1971 David Kolb developed the Learning Style Inventory (LSI) to assess individual learning styles. The instrument was created as an educational tool to enhance an individual's understanding of the learning process through experience and their individual approach to learning. The LSI can be used as a starting point for exploring how an individual learns best. The instrument also serves as a research tool for investigating experiential learning theory (ELT) and the characteristics of individual learning styles (Kolb \& Kolb, 2005).

"ELT has been widely accepted as a useful framework for learning-centered educational innovation, including instructional design, curriculum development, and life-long learning" (Kolb \& Kolb, 2005, p.8). The LSI is not intended for use to predict behavior for job placement or assigning learners to different educational treatments. An individual's learning style is not to be considered a fixed trait; rather learning style is a dynamic state arising from an individual's balancing of the two opposing experiences - experiencing/conceptualizing and acting/reflecting (Kolb \& Kolb, 2005).

Five versions of the Learning Style Inventory have been published. Table 1 provides a summary of each of the versions. 
Table 1 - Learning Style Versions (Kolb \& Kolb, 2005)

\begin{tabular}{|c|c|l|}
\hline Ver & Year & \multicolumn{1}{c|}{ Description } \\
\hline 1 & 1969 & $\begin{array}{l}\text { Developed as an experiential exercise designed to help learners understand the process of experiential } \\
\text { learning and their unique style of learning from experience. "The term learning style was coined to describe } \\
\text { these individual differences in how people learn" (Kolb \& Kolb, 2005, p.9). } \\
\text { The final version had 9 items that was further refined to include six scored items. } \\
\text { Validity was established in a number of fields. The results of this research provided empirical support for } \\
\text { the most complete and systematic statement of ELT. Several studies identified psychometric weaknesses of } \\
\text { the instrument, particularly low internal consistency reliability and test-retest reliability. }\end{array}$ \\
\hline 2 & 1985 & $\begin{array}{l}\text { Six new items were selected to increase internal reliability (alpha) and added to each scale making 12 scored } \\
\text { items on each scale. Wording on all items was simplified to a 7 grade reading level and the format was } \\
\text { changed to include sentence stems e.g., "When I learn...". } \\
\text { A new more diverse normative group of 1446 men and women was created. }\end{array}$ \\
\hline $2 \mathrm{a}$ & 1993 & $\begin{array}{l}\text { In 1991 Veres, Sims, and Locklear published a reliability study of a randomized version of the LSI 2 that } \\
\text { showed a small decrease in internal reliability but a dramatic increase in test-retest reliability with the } \\
\text { random scoring format. Version 2a was published as a research version to study this format. } \\
\text { Research with the LSI 2 continued to establish validity for the instrument. While internal reliability } \\
\text { remained high in independent studies, test-retest reliability remained low. }\end{array}$ \\
\hline 3 & 1999 & $\begin{array}{l}\text { The randomized format was adopted in a revised self-scoring and interpretation booklet that includes } \\
\text { simplified scoring. LSI 3 continued to use the LSI 2 normative reference group. }\end{array}$ \\
\hline 3.1 & 2005 & $\begin{array}{l}\text { LSI 3.1 modified LSI 3 to include new normative data. This revision includes new norms that are based on a } \\
\text { larger, more diverse and representative sample of 6,977 LSI users. } \\
\text { Results from seven different studies of the LSI 3.1 suggest that the scales show good internal consistency } \\
\text { reliability across a number of different populations. In several studies, test-retest correlation coefficients } \\
\text { range from moderate to excellent. }\end{array}$ \\
\hline
\end{tabular}

The format of the LSI is designed such that the individual responds as they would respond to a learning situation. Additionally, the individual rank orders their preferences for abstract, concrete, active, and reflective abilities and effectively resolves the conflict between the abstract-concrete and active-reflective dimensions. All versions of the LSI have the same format. A short questionnaire asks the individuals to rank four sentence endings that correspond to the four learning modes - Concrete Experimentation (experiencing), Reflective Observation (reflecting), Abstract Conceptualization (thinking), and Active Experimentation (doing). The individuals rank their relative choice preferences among the four modes of the learning style (Kolb \& Kolb, 2005).

The LSI evaluates six variables: four primary scores that measure the individual's relative emphasis on the four learning abilities - Concrete Experience (CE), Reflective Observation (RO), Abstract Conceptualization (AC), and Active Experimentation (AE). An additional two measures that are a combination score that evaluates individual's preference for abstractness over concreteness (AC-CE) and action over reflection (AE-RO). The four learning style types - Accommodator, Diverger, Assimilator, and Converger, are determined by dividing the AC-CE and AE-RO scores at the fiftieth percentile of the total norm group and plotting them on the Learning Style Grid (Kolb \& Kolb, 2005). "Recent theoretical and empirical research is showing that the original four learning styles can be refined to show nine distinct styles" (Kolb \& Kolb, 2005, p. 15).

\section{Prior Learning Style Research in Accounting}

There has been considerable interest in ELT/LSI research in accounting education. According to Kolb and Kolb (2005) twenty-two studies have been performed in the accounting field. Seven of the studies were performed between 1971 and 1984 and 15 studies were performed between 1985 and 1999. The research has explored two paths related to ELT. The first is a comparative assessment of learning style preferences of accounting majors and practitioners including changes in learning style over the stages of a career in accounting and the second, focuses on using ELT to design instruction in accounting and studying relationships between learning style and performance in accounting courses (Kolb \& Kolb, 2005).

Clarke, Oshiro, Wong, and Yeung (1977) examined accounting students preferred learning styles. The results indicated that accountants tend to be convergers (McKee, Mock, \& Ruud, 1992). Baldwin and Reckers (1984) reviewed learning style preferences of 187 accounting majors ranging from undergraduate class levels to 
upper class levels. Results indicated that accounting majors have different learning style preferences than other business majors and that class level makes a difference in the preferred learning style. The average learning style score for junior and graduate student accounting majors fell in the converger quadrant. The mean score for seniors fell in the accommodator quadrant, while the mean score for sophomores was in the assimilator quadrant. This is consistent with the concept that specific learning style preference is acquired as the student progresses through the educational process. Baker, Simon, and Bazeli (1986) assessed the learning style preferences of 110 senior accounting majors and found $39 \%$ of the students to demonstrate a converger learning style preference.

A study performed of 266 Canadian accounting majors and 148 accounting professionals indicated that most of the accounting students fell within the diverger category (although very close to the classification cut-off point and indicates more of a balance learning style). The authors noted "There appeared to be an increasing preference for the convergent learning style as accounting students and graduates are exposed over time to a greater concentration of accounting education and related work experiences" (Brown \& Burke, 1987, p. 204).

Baker, Simon, and Bazeli (1987) were the first to use the LSI 2 version in examining accounting students. Baker et al. (1987) surveyed the learning style preferences of 207 sophomore business students enrolled in an introduction to accounting class. The results showed a preference for the assimilator learning style. This study is worthwhile in that it can be compared to Baldwin and Reckers (1984) study, which also demonstrated a preference towards the assimilator learning style of sophomores.

Collins and Milliron (1987) surveyed learning style preferences of 334 practicing accountants in large and small CPA firms and a large industrial company. The findings suggested a dominant converger learning style preference across the specialties within the firm and a higher concentration of converger learning style among advanced accounting practitioners. Overall, 53\% of the professional accountants were classified into the converger style.

Jenkins and Holley (1991) compared the learning style preferences of male and female accounting students to provide further insight into gender performance differentials. Findings revealed that both men $(n=46)$ and women $(\mathrm{n}=52)$ enrolled in an Intermediate Accounting I class preferred the assimilator learning style.

Stout and Ruble (1991) surveyed a large and diverse sample of upper level accounting majors using three different forms of the LSI - original, revised, and scrambled. The study found the assimilator style to be dominant for both junior and senior accounting majors. Stout and Ruble raised concerns of the LSI as a measuring and classification instrument.

Togo and Baldwin (1990) using the original LSI instrument, examined whether students demonstrating a converger learning style preference would perform better in an introductory financial accounting class. The findings indicated that the 46 out of 218 students with a converger learning style preference performed better on the multiple choice test.

Geiger (1992) extended the earlier work of Togo and Baldwin (1991) using the LSI 2 version. The study was administered to 157 students (sophomores) taking an introductory accounting class. While learning style was found to be significantly related to course performance, the results contradict Togo and Baldwin (1991) who found convergers outperformed their peers. In Geiger's study assimilators outperformed their peers. Also noteworthy is that the instructor possessed an assimilator learning style. These results seem to support the notion that students with learning styles congruent with their instructors perform better than those with different learning styles.

McKee, et al. (1992) examined 179 Norwegian accounting students and 71 United States accounting students with varying experience levels. The study used the original instrument as the authors were unaware of the LSI 2 version. The results indicated that the Norwegian accounting students learning style preference was assimilator while the United States students' dominant learning style was converger.

All in all, the results are mixed potentially indicating that class level and cultural background can influence learning style preference. 


\section{Using Experiential Techniques in the Accounting Curriculum}

As cited by Beard and Wilson (2006) the Oxford Dictionary describes experience as -

The fact of being consciously the subject of a state or condition; of being consciously affected by an event; a state or condition viewed subjectively; an event by which one is affected; and, knowledge resulting from actual observation or from what one has undergone.

The definitions provided in the Oxford Dictionary "connect both the action and the sensing or thinking about the action (Beard \& Wilson, 2005, p.17). Hawtrey (2007) defines experiential learning as "the incorporation of active, participatory learning opportunities in the course. It is sometimes called situational learning" (p. 144). Both definitions can clearly be seen in Kolb's learning cycle (see Figure 1).

Experiential learning, or active, involved learning, learning by doing, or interactive learning requires that students do not passively acquire knowledge rather the student is actively involved in the learning process. Supporters of experiential learning believe that it promotes greater interest in the subject material, enhances intrinsic learning satisfaction, increases understanding and retention of course material, develops the desire and ability to be continuous learners, improves communication, and interpersonal, problem solving, analytical thinking, and critical thinking skills of the students (Brickner \& Etter, 2008). Experiential learning has resulted in positive outcomes. Most experts agree that when students take an active role in the learning process the student's learning is optimized (Smart \& Csapo, 2007). "Students remember only a fraction of what they hear but a majority of what they actively do" (Hawtrey, 2007, p.145).

Kolb's Learning Style Inventory appeals to accounting education researchers likely due to the survey instrument being brief and straightforward. This makes it useful to the researchers and for providing feedback on the learning process to the individuals. Faculty can use their understanding of learning styles to plan courses, assignments, and programs that include the entire learning cycle experiences. In Kolb's learning process there are four distinct, but interrelated stages. In the first stage

... learners acquire information by immediate concrete experience from full involvement, without bias, in the new experience. Second, a stage of reflective observation on the experience occurs, where the learner organizes and examines the experiential data from different perspective. Third, a stage of abstract conceptualization occurs, where the learners develop generalizations that help them integrate their observations into sound theories or practices. Finally, the fourth stage of active experimentation, learners use these generalizations as guides to new, more complex situations. The process then repeats itself, with the new information re-entering the concrete experience stage, and so on (Duff, 1998, p.337).

Learners can enter and cycle through at any stage and tend to have strengths in a particular learning stage. Weaker preferences in the learning cycle can be strengthened to aid the learner in adapting to various teaching styles while strengths can also enhance the learning outcomes. Table 2 relates learning styles with their preferred instructional delivery method in a formal learning environment.

Table 2 - Learning style preferences in formal learning situations (Francis, et al., 1995)

\begin{tabular}{|l|l|}
\hline Learning style & Instructional Method in a Formal Learning Environment \\
\hline Diverger & Prefer working in groups, listening with an open mind, and receiving personal feedback. \\
\hline Accomodators & $\begin{array}{l}\text { Prefer working with others to get assignments done, setting goals, performing field work, and testing } \\
\text { different approaches to completing a project. Tend to solve problems in an intuitive trial and error } \\
\text { method relying on other people for information. }\end{array}$ \\
\hline Assimilators & Prefer readings, lectures, exploring analytical models, and thinking things through. \\
\hline Convergers & $\begin{array}{l}\text { Prefer experimenting with new ideas, simulations, laboratory assignments and practical applications. } \\
\text { Tend to do well on conventional intelligence tests where there is a single correct answer. }\end{array}$ \\
\hline
\end{tabular}


Using our knowledge of the learning styles and results of previous studies, educators can develop experiences or apply proven experiential learning practices in the learning environment.

Accounting faculty may use an understanding of the student's and their own learning styles to plan assignments, courses, and programs to include the entire cycle of learning. This provides the students opportunities to use their preferred style of learning while also practicing and developing other styles. To be fully effective, a student's education should include the full cycle of learning experiences and the ability to use a variety of learning styles (Francis, et al., 1995, p. 36).

Brent and Harvey (2005) provide ten ways to engage students both mentally and physically. Some of these recommendations include: structure sessions to include input, activity, reflection, and planning; change what you do every 20 minutes; use a range of individual, paired, and small group activities to create variety, build relationships, and get ideas; solicit constructive and developmental feedback; use open room layouts; minimize one-way conversations.

Webb (2006) identified some main methods to apply in an active learning environment. They include: syndicate work; case studies; practical exercises; management and soft skills activities; and, role plays.

Some recent accounting studies have shared positive experiences of applying active learning in the classroom. Healy and McCutcheon (2008) in a qualitative study examined accounting students' experiences of active learning approaches. Their results indicated that all students experienced benefits including life-long skills such as team-working, confidence, and self-learning. Some of the active learning activities included case study and problem-based learning with in-class group presentations.

Brickner and Etter (2008) provided in-class and out-of-class strategies to promote active learning in a principles of accounting course. To facilitate greater student interest and participation in class one activity involved providing students with "guided notes." These notes, provided in advance of the class, are a partial set of lecture notes. The students are required to print them off, bring them to class and then fill in the missing information. The instructors also break the classroom time down into 15 minute segments to maintain student interest and attention. In between these segments the instructors slot in an active learning exercise. Some examples include walking around the classroom asking questions, have the students reflect on their notes and assimilate the information, mini-quizzes, and probing or motivating questions. At the end of the class the instructors allow a few minutes for the students to reflect upon the day's material and summarize in a "minute paper." Their findings have been that the "minute paper" facilitates learning. Out-of-class active learning activities include attending business student organization meetings, preparing article summaries, and reviewing annual reports.

Savage, Norman, and Lancaster (2008) show the movie, Rogue Trader, to teach the COSO internal control framework. The instructors have found this type of experiential learning is fun, memorable, and can make the material more relevant.

Lavoie and Rosman (2007) applied active learning techniques to an online Master of Science Accounting program. Courses were designed to accommodate multiple learning styles and maximize the learners' experience. The courses combine multiple student-centered activities to accomplish the learning objectives. Activities include group tasks that include information sharing and applying judgments, engaging in online threaded discussions, using outside resources to apply to in course assignments.

Other activities used to promote active learning include bringing a news clipping that makes a link between the academic subject matter and current affairs (Hawtrey, 2007) and using service learning in a tax course. The service learning experience has students participate in the Volunteer Income Tax Assistance (VITA) program. The benefits found with this activity are engaging students in critical analysis and problem solving (Long \& Kocakulah, 2007). 


\section{FUTURE RESEARCH}

To date most studies have been cross-sectional that is looking at a group of students at a particular time. A time-series study following accounting majors from freshman year through post college employment that examines the potential for changes in learning styles as they progress through more complex classes would help provide support on changing learning styles throughout post secondary school and into professional employment. Research that examines whether certain accounting classes or teaching styles require students to adapt their learning styles to particular course curriculum or instructional design would be useful. Further research could examine the dynamics between the student and teacher interaction.

With the changing demographics and more minorities entering post-secondary education, more research is needed on the learning styles of minority accounting students.

Additional research that broadens the research to incorporate more than one of the approaches to learning styles (personality, information processing, social interaction, and instructional preferences) should be considered.

With the impending adoption of international financial reporting standards and the U.S. moving towards a principles-based approach (versus rules-based) it would be interesting to see if the learning styles of future accountants will need to change. Norwegian accounting students whose course instruction favored concepts portrayed the assimilator learning style compared to U.S. students who tend to be convergers (McKee et al., 1992).

\section{SUMMARY}

This paper examines Kolb's (1984) Experiential Learning Theory and Learning Style Inventory, presents a summary of some research examining accounting students' learning style preferences, and provides examples of activities to incorporate into the instructional environment that encourages learning through experience.

\section{AUTHOR INFORMATION}

Mary McCarthy, CPA, CFA has over 18 years in the financial services serving in various leadership positions. She is currently pursuing her doctorate degree in accounting at Nova Southeastern University in Fort Lauderdale, Florida. She holds a master's degree in Finance from the University of Connecticut and a bachelor's of science degree in accounting from Central Connecticut State University. She is a certified public accountant (State of Connecticut) and a CFA charterholder. As she transitions to an academic career she has a keen interest developing instructional curriculum that appeals and enhances the student's learning process.

\section{REFERENCES}

1. Baker, R. E., Simon, J. R. \& Bazeli, F.P. (1986). An assessment of the learning style preferences of accounting majors. Issues in Accounting Education, Spring, 1-12.

2. Baker, R.E., Simon, J. R. \& Bazeli, F.P. (1987). Selecting instructional design for introductory accounting based on the experiential learning model. Journal of Accounting Education, 207-226.

3. Baldwin, R.A., \& Reckers, P.M., (1984). Exploring the role of learning style research in accounting education policy. Journal of Accounting Education, Fall, 63-76.

4. Beard, C. \& Wilson J. P. (2006). Experiential Learning $2^{\text {nd }}$ edition A best practice handbook for educators and trainers. Kogan Page: London.

5. Brent L. \& Harvey, T. 10 ways to make training active. (2005). Training Journal, August, 48.

6. Brickner, D. R. \& Etter E. R.. (2008). Strategies for promoting active learning in a principles of accounting course. Academy of Education Leadership Journal, 12(2), 87- 93.

7. Brown, H. D. \& Burke, R. C. (1987). Accounting education: A learning-styles study of professionaltechnical and future adaptation issues. Journal of Accounting Education, Fall, 187-206.

8. Clarke, D, Oshiro, Wong, S. C. \& Yeung, M. (1977). A study of the adequacy of the learning environment for business students in Hawaii in the fields of accounting and marketing. Unpublished paper. University of Hawaii, USA. 
9. Collins, J.H., \& Milliron, V.C. (1987). A measure of professional accountants' learning style. Issues in Accounting Education, Fall, 193-206.

10. Duff, A. (1998). Objective tests, learning to learn and learning styles: A comment. Accounting Education, 7(4), 335-345.

11. Francis, M.C., Mulder, T. C. \& Stark. J.S. (1995). Intentional Learning: A Process for Learning to Learn in the Accounting Curriculum. American Accounting Association: Sarasota, FL.

12. Geiger, M. (1992). Learning styles of introductory accounting students: An extension to course performance and satisfaction. Accounting Educators' Journal, 4(1), 22-39

13. Hawtry, K. (2007). Using experiential techniques. Journal of Economic Education, Spring, $143-152$.

14. Healy, M. \& McCutcheon, M. (2008). Engagement with active learning: Reflections on the experience. The Irish Accounting Review, 15(1), 31-49.

15. Kolb, D.A. (1984) Experiential Learning: Experience as the Source of Learning and Development. Prentice-Hall, Inc. Englewood Cliffs, NJ.

16. Kolb, A. \& Kolb, D. A. (2005) The Kolb Learning Style Inventory - version 3.12005 Technical Specifications. Retrieved June 10, 2009 http://www.learningfromexperience.com.

17. Kolb, D.A., Boyatizis, R.E., \& Mainemelis, C. (1999) Experiential Learning Theory: Previous Research and New Directions. Retrieved June 10, 2009 http://www.learningfromexperience.com/html/research_library.html.

18. Jenkins, E.K., \& Holley, J. H. (1991). Learning style preferences and the prospective accountant: Are there gender differences? The Woman CPA, Fall, 46-49.

19. McKee, T.E., Mock, T. J. \& Ruud, T. F. (1992). A comparison of Norwegian and United States accounting students' learning style preferences. Accounting Education, 1(4), 321-341.

20. Murrell, P. H., \& Claxton, C. S. (1987). Experiential Learning Theory as a Guide for Effective Teaching. Journal of the Association for Counselor Education and Supervision, 27, 4-14.

21. Savage, A., Strand, C. S. \& Lancaster, K. A. S. (2008). Using a movie to study the COSO internal control framework: An instructional case. Journal of Information Systems, 22(1), 63-76.

22. Smart, K.L. \& Csapo, N. (2007) Learning by doing: Engaging students through learner-centered activities. Business Communication Quarterly, 70(4), 451-457.

23. Stout, D. E., \& Ruble, T. L. (1991). The learning style inventory and accounting education research: A cautionary view and suggestions for future research. Issues in Accounting Education, 6(1), 41-52.

24. Togo, D.F., \& Baldwin, B. A. (1990) Learning style: A determinant of student performance for the introductory financial accounting course, Advances in Accounting, 7, 189-199.

25. Webb, L. (2006). Learning by doing. Training Journal, March, 36 


\section{NOTES}

